\title{
Balance between denitrification and microalgal incorporation of nitrogen in microtidal sediments, NE Kattegat
}

\author{
Kristina Sundbäck* ${ }^{*}$ Alison Miles \\ Botanical Institute, Marine Botany, Göteborg University, Box 461, 40530 Göteborg, Sweden
}

\begin{abstract}
The importance of denitrification and microphytobenthos for nitrogen removal and retention was studied over an annual cycle in 2 microtidal shallow-water sediments, 1 sandy and 1 silty, on the west coast of Sweden. Denitrification rates (isotope-pairing) and oxygen and inorganic nitrogen fluxes were measured in undisturbed sediment incubated in the laboratory at in situ temperature, at mean monthly light intensities and in the dark. Algal $\mathrm{N}$ assimilation rates were calculated from primary productivity and $\mathrm{N}$ retention in the microphytobenthic biomass from chlorophyll a concentrations. Denitrification ranged from ca 1 to $1360 \mu \mathrm{mol} \mathrm{N} \mathrm{m} \mathrm{d}^{-1}$, being generally 1 order of magnitude higher in the silty sediment. The sandy sediment was net oxygen producing throughout the year and the silty sediment during most of the year. The rate of algal $\mathrm{N}$ assimilation calculated from daily net primary productivity was 30 to $7000 \mu \mathrm{mol} \mathrm{N} \mathrm{m} \mathrm{N} \mathrm{d}^{-1}$, generally exceeding denitrification by 1 to 2 orders of magnitude. The low denitrification rates are explained by competition for external and internally circulated substrate by microalgae, and a general negative effect of microalgal photosynthesis on denitrifiers. The results suggest that, in northern climate microtidal sediments, microphytobenthic $\mathrm{N}$ incorporation is more important than $\mathrm{N}$ removal by denitrification.
\end{abstract}

KEY WORDS: Sediment · Nitrogen · Denitrification · Primary production · Microphytobenthos Resale or republication not permitted without written consent of the publisher

\section{INTRODUCTION}

To counteract marine eutrophication, it is crucial to know not only the sources but also the sinks of nitrogen. In shallow-water sediments, which are recognized as highly productive areas (Underwood \& Kromkamp 1999), bioavailable nitrogen can be removed or retained in 3 ways: (1) bacterial denitrification, (2) assimilation by primary producers and (3) burial of particulate matter. However, actual quantitative knowledge regarding the balance between these processes is still limited, as they have seldom been assessed simultaneously. The 'classical' rule of thumb that ca 40 to $50 \%$ of the $\mathrm{N}$ load is removed by denitrification in shallow estuaries (Seitzinger 1988) is often applied for areas differing widely in both environmen-

*E-mail: kristina.sundback@marbot.gu.se tal variables and ecosystem structure. Some recent measurements, however, point to a rather low denitrification capacity of shallow-water sediment systems (Rysgaard et al. 1995, Dalsgaard 1999), suggesting that other N-retaining processes, such as incorporation and retention in primary producers, may be more important.

Traditionally, benthic $\mathrm{N}$ cycling in sediments has been studied in relation to heterotrophic processes, such as bacterial and faunal activities. However, the coupling between primary producers and $\mathrm{N}$ turnover in shallow-water sediment areas has begun to gain more attention (cf. Currin et al. 1996, Pihl et al. 1996, Viaroli et al. 1996, Risgaard-Petersen \& Ottosen 2000). Among the main primary-producing components in such areas, sediment-associated microalgae (microphytobenthos) have the widest spatial distribution, accounting for $50 \%$ or more of the primary production 
in shallow estuaries (Underwood \& Kromkamp 1999). Moreover, while the macroscopic primary producers (seagrasses and floating macroalgae) are, at least in northern latitudes, restricted to the warm season (Pedersen \& Borum 1993, Pihl et al. 1996), the microphytobenthos is present throughout the year (Daehnick et al. 1992, Rysgaard et al. 1995, Sundbäck et al. 1996). Thus, the microphytobenthos can be expected to be a year-round sink for nitrogen. Besides assimilating inorganic $\mathrm{N}$, and thereby competing with bacteria (Rysgaard et al. 1995), microphytobenthic oxygenation of the sediment affects nitrification and denitrification rates (Risgaard-Petersen et al. 1994). In microtidal areas, the importance of the microphytobenthos for $\mathrm{N}$ retention might exceed that in intertidal areas, as the generally clear water column allows photosynthesis to occur throughout the daylight period, sometimes down to a depth of $10 \mathrm{~m}$ or more (Sundbäck \& Jönsson 1988, Herndl et al. 1989).

This paper was inspired by the fact that the balance between algal $\mathrm{N}$ assimilation and bacterial denitrification in sediments has hardly ever been discussed, although both processes remove dissolved bioavailable $\mathrm{N}$ from the system. Denitrification, which removes nitrogen permanently, is of particular importance in areas vulnerable to eutrophication, such as nontidal and microtidal waters in the Baltic Sea area (Nixon 1995). Results from a recent seasonal, European-scale field study (Dalsgaard 1999) indicated that, in microtidal sediments, N-retention by microalgae might be more important than $\mathrm{N}$ removal by denitrification, particularly in low-nitrate areas in northern latitudes. However, this tentative conclusion was based on a preliminary comparison of hourly rates. The purpose of this paper is to obtain a more ecologically relevant comparison of the balance between algal $\mathrm{N}$ assimilation and denitrification by considering these 2 processes on a longer time scale (days, months, year). The balance estimations are based on recalculations of data from an annual study (Sundbäck et al. 2000) at 2 sites with differing sediment characteristics, 1 sandy and 1 silty, on the Swedish west coast.

\section{MATERIAL AND METHODS}

Study sites. The study was conducted in 2 shallow brackish-water bays (salinity range 18 to 34 ) on the west coast of Sweden, at the transition between the Kattegat and Skagerrak, an area where the tidal amplitude is only 10 to $20 \mathrm{~cm}$. Two sites (Vallda $57^{\circ} 29^{\prime} \mathrm{N}$, $11^{\circ} 56^{\prime} \mathrm{E}$, and Rörtången $57^{\circ} 55^{\prime} \mathrm{N}, 11^{\circ} 46^{\prime} \mathrm{E}$ ) were studied; Vallda is dominated by silty sand and Rörtången by sandy silt, and the mean loss on ignition $(2 \mathrm{~h}$ at $500^{\circ} \mathrm{C}$ ) is 1.4 and $4.9 \%$, respectively. Mean water depth at the sampling sites was 0.2 and $0.5 \mathrm{~m}$, respectively. Oxygen penetration into the sediment was generally greater at the sandier site $(3.2 \mathrm{~mm} \pm \mathrm{SE} 0.3)$ than at the silty site $(1.6 \mathrm{~mm} \pm \mathrm{SE} 0.1)$. Over the annual cycle, water temperature varied between -1 and $30^{\circ} \mathrm{C}$. During the period November to April water temperatures were below $10^{\circ} \mathrm{C}$, with both sites being covered by ice during January to March.

Both study sites are characterized by low values of inorganic nitrogen, maximum winter values of $\mathrm{NO}_{3}$ (including $\mathrm{NO}_{2}$ ) being $6 \mu \mathrm{M}$ at Vallda and $30 \mu \mathrm{M}$ at Rörtången (Sundbäck et al. 2000). Summer concentrations were generally $<1 \mu \mathrm{M}$ at both sites. Mean monthly $\mathrm{NH}_{4}$ concentrations varied between 0.5 and $3.6 \mu \mathrm{M}$ at Vallda and between 0.2 and $6.2 \mu \mathrm{M}$ at Rörtången during the warm season.

Sampling. The sampling design was hierarchical, i.e. at both sites (50 km apart), 2 stations (50 m apart) were sampled: Stns A and B at Vallda and Stns C and D at Rörtången. Samples were taken once per month, on 11 occasions (12 for chlorophyll $a$ [chl a] and oxygen flux) between February 1997 and February 1998. On each occasion 2 types of sediment cores were taken: (1) cores (i.d. $8 \mathrm{~cm}, 24 \mathrm{~cm}$ long) for measurements of oxygen and nutrient flux, denitrification rates, chl a content, and macrofauna ( $\mathrm{n}=3$ per station), and (2) cores (i.d. $6.7 \mathrm{~cm}$, $10 \mathrm{~cm}$ long) for oxygen penetration and sediment characteristics ( $\mathrm{n}=3$ per station).

Incubation procedure. Intercalibrated, standardised techniques were applied to all incubations and analyses (Dalsgaard et al. 2000). Intact sediment cores were incubated in the laboratory under light and dark conditions, at in situ temperature in site water.

For measurements of oxygen and nutrient fluxes, and rates of denitrification, the intact sediment cores (i.d. $8 \mathrm{~cm}, 12 \mathrm{~cm}$ sediment $+12 \mathrm{~cm}$ overlying water) were incubated in tanks containing ca $70 \mathrm{l}$ of unfiltered water from the respective site. The tank water was continuously circulated $\left(201 \mathrm{~min}^{-1}\right)$ and water in the cores was continuously stirred by Teflon-coated magnets $(6 \mathrm{~cm}$ above the sediment surface, turning rate of 60 to $70 \mathrm{rpm})$. This ensured thorough mixing of the water column without causing sediment resuspension. The cores were left overnight without lids to settle and fluxes were measured the following day. Before incubations were started, cores were pre-incubated at the experimental irradiance level for $1 \mathrm{~h}$ and the headwater in the cores exchanged. Three cores from each station, together with 1 or 2 cores with overlying water only (used for blank correction), were incubated. Light was provided by individual 25 or $50 \mathrm{~W}$ halogen bulbs over each core with incubations being run over the natural daylight period. The light intensity used represented the daily mean for that month (values from the Danish Institute of Agricultural Sciences, Research 
Center Foulum, Denmark) and varied between 86 and $618 \mu \mathrm{mol}$ photons $\mathrm{m}^{-2} \mathrm{~s}^{-1}$. Incubation time was set so that changes in oxygen concentration within the cores did not exceed $20 \%$.

Light and dark fluxes of nutrients and oxygen were measured on the same cores, and following the incubation, each core was sampled for chl a and sieved for macrofauna (500 $\mu \mathrm{m}$ mesh size). Denitrification measurements were carried out on separate cores and light and dark measurements were not paired as cores were slurried at the end of the incubation period. Inorganic nitrogen $\left(\mathrm{NO}_{3}+\mathrm{NO}_{2}\right.$ and $\left.\mathrm{NH}_{4}\right)$ was analysed on a TRAACS 800 autoanalyser (Braun \& Lubbe) using standard colorimetric methods (Grasshoff et al. 1983).

Primary productivity, biomass and $\mathrm{N}$ assimilation of microphytobenthos. Microphytobenthic primary productivity was calculated from oxygen flux measurements (Winkler titration; Strickland \& Parsons 1972). Oxygen flux in the light was used as a measure of net production (NP), and gross production (GP) was calculated as the sum of NP and community respiration (CR) in the dark. For practical reasons, it was assumed that $\mathrm{CR}$ in the light equalled respiration in the dark (see 'Discussion: Methods'). For conversion to carbon produced, a photosynthetic quotient of 1.2 was assumed (Wetzel \& Likens 1991). As the irradiance used for the incubations represented a daily mean of the light hours of each month, daily values of primary production were calculated from hourly values by multiplying by the number of daylight hours. Annual primary productivity was calculated by multiplying the daily rate for each month by the number of days in each month and summing up to one year. Values for January 1998 were calculated as a mean of the measured values for December 1997 and February 1998.

The benthic microalgal biomass in the top $5 \mathrm{~mm}$ of sediment was measured as amount of chl a. Samples for chl a were taken from the flux cores at the end of the incubation period, using a $20 \mathrm{ml}$ cut-off disposable syringe. Pigment concentration was measured spectrophotometrically (Lorenzen 1967) in frozen samples after extraction with $90 \%$ acetone.

$\mathrm{N}$ assimilation by the microphytobenthos was calculated from daily primary production values (NP and GP), assuming a C/N molar ratio of 9 (see 'Discussion: Methods' for justification of this ratio). Retention of $\mathrm{N}$ in the biomass was calculated from chl a values assuming a mean C/chl a ratio of 30 (de Jonge 1980, Sundbäck et al. 2000).

Denitrification. Sediment denitrification was measured, in light and dark, using the isotope pairing technique (Nielsen 1992). Although this method discriminates between denitrification supported by $\mathrm{NO}_{3}$ in the water column $\left(D_{\mathrm{w}}\right)$ and nitrification-coupled denitrification $\left(D_{\mathrm{n}}\right)$, for the purpose of this study only total denitrification rates $\left(D_{\text {tot }}\right)$ will be considered. ${ }^{15} \mathrm{NO}_{3}$ (100 mM Na ${ }^{15} \mathrm{NO}_{3}, 99.6$ at. \%, Europa Scientific Ltd) was added to the headspace water to a final concentration of ca. $60 \mu \mathrm{M}^{15} \mathrm{NO}_{3}$ (ca. $90 \%{ }^{15} \mathrm{NO}_{3}$ ). The $\mathrm{NO}_{3}$ concentration was measured prior to and following the addition of ${ }^{15} \mathrm{NO}_{3}$, in order to calculate the ${ }^{14} \mathrm{~N} /{ }^{15} \mathrm{~N}$ ratio in the $\mathrm{NO}_{3}$ pool. The depth of the oxic zone in the sediment was measured using oxygen microelectrodes (Revsbech 1989) in order to calculate the optimal incubation time. For extraction of the $\mathrm{N}_{2}$ samples, $2 \mathrm{ml}$ $\mathrm{ZnCl}_{2}\left(1 \mathrm{~g} \mathrm{ml}^{-1}\right)$ was added to the water phase and then the sediment and water were gently but quickly mixed. A sample of the slurry was transferred to a $12.5 \mathrm{ml}$ gas-tight vial and a further $250 \mu \mathrm{l}$ of $\mathrm{ZnCl}_{2}$ was added. The isotope ratio of $\mathrm{N}_{2}$ was analysed by mass spectrometry at the National Environmental Research Agency, Silkeborg, Denmark. Daily rates of total denitrification $\left(D_{\text {tot }}=D_{\mathrm{w}}+D_{\mathrm{n}}\right)$ were calculated by multiplying the hourly rate in light with the number of daylight hours and the hourly rate in the dark by the number of dark hours. Annual denitrification was calculated in the same way as annual primary production.

Data analyses. Differences between sites and stations were tested using 2-way ANOVA (unnested and nested), with place and time as main factors. Homogeneity of variances was tested using Cochran's test, and when variances were found to be heterogeneous, the data were transformed according to Underwood (1997). Differences were accepted as significant at $\mathrm{p}<$ 0.05. Daily values of denitrification could not be tested, as light and dark measurements were not paired. Pearson correlation analyses were used to look for correlations between variables.

\section{RESULTS}

\section{Algal biomass and primary productivity}

Mean chl a concentrations varied between 16 and $106 \mathrm{mg} \mathrm{m}^{-2}$ (equivalent to 480-3150 $\mathrm{mg} \mathrm{C} \mathrm{m}^{-2}$, applying a mean $\mathrm{C} / \mathrm{chl}$ a ratio of 30 ) (Fig. 1A). Concentrations were generally higher (2-way ANOVA, site $\times$ time interaction, $\mathrm{p}=0.018$ ) at Vallda (sandy) than Rörtången (silty). The mean daily net primary productivity (NP) varied between 0 and $764 \mathrm{mg} \mathrm{C} \mathrm{m}^{-2} \mathrm{~d}^{-1}$, with peak values from June to September (Vallda) and June to October (Rörtången) (Fig. 1B). Corresponding daily gross productivity (GP) varied between 5 and $1547 \mathrm{mg} \mathrm{C} \mathrm{m}^{-2}$ $\mathrm{d}^{-1}$ (not shown). The sandy site showed NP throughout the year, while the silty site showed net oxygen consumption in winter and occasionally in spring and early autumn (1 station only). There was no significant difference in NP between the 2 sites. However, a difference between stations was found at Rörtången, with NP at 
A
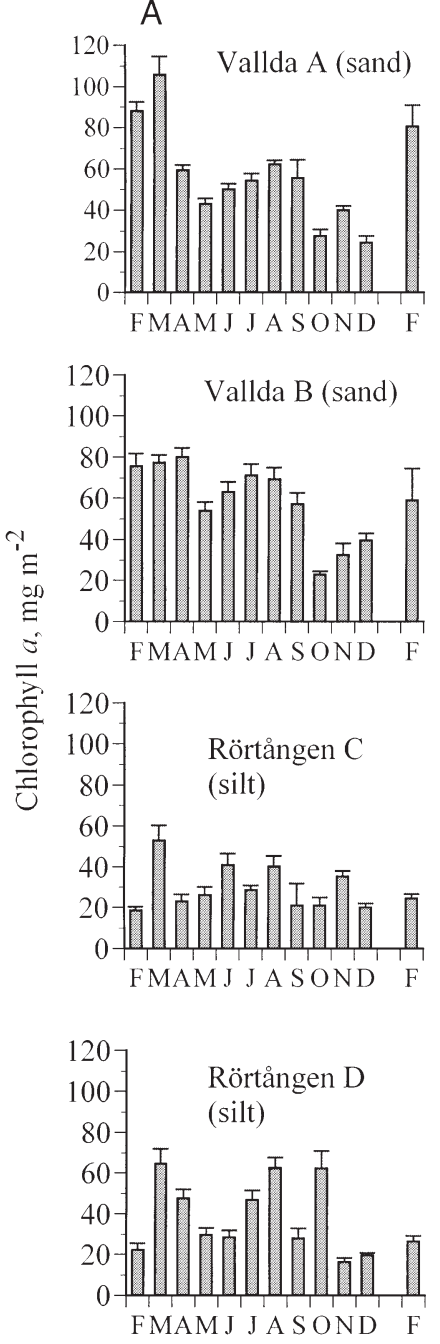

B
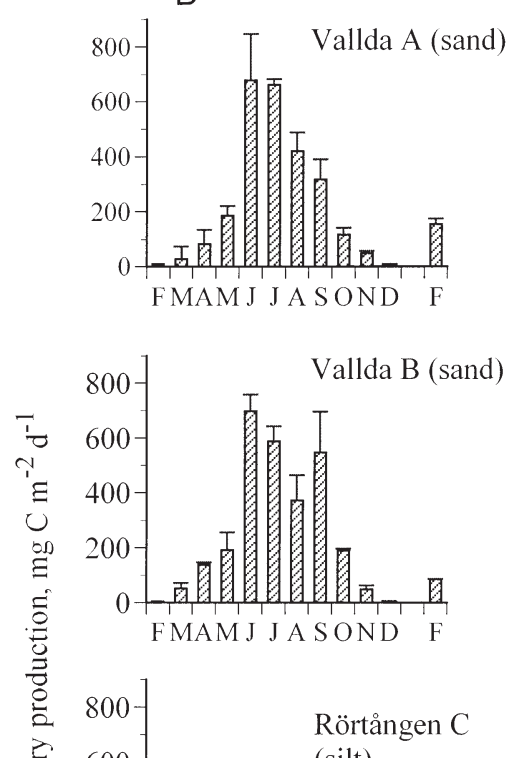

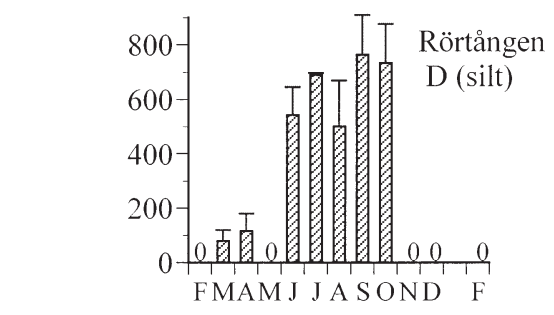

Month

Fig. 1. (A) Annual variation of chlorophyll $a$ in the top $5 \mathrm{~mm}$ of sediment and (B) daily net primary production of microphytobenthos for the 4 stations. Means of 3 replicates + SE are shown

and $\mathrm{B}$ ), and 2.6 and $8.7 \mathrm{~mol} \mathrm{C} \mathrm{m}^{-2} \mathrm{yr}^{-1}$ (or 31.7 and $104.1 \mathrm{~g} \mathrm{C} \mathrm{m}^{-2} \mathrm{yr}^{-1}$ ) for the 2 silty stations (Stns $\mathrm{C}$ and $\mathrm{D}$ ), respectively (Table 1). Corresponding GP rates were approximately twice as high (Table 1).

\section{Nitrogen assimilation and retention by microphytobenthos}

As rates of $\mathrm{N}$ assimilation are based on net primary productivity $\left(A_{\mathrm{NP}}\right)$, they show the same annual pattern as primary productivity, with values ranging from 0 to $7060 \mu \mathrm{mol} \mathrm{N} \mathrm{m}^{-2} \mathrm{~d}^{-1}$ (Fig. 2A). On an annual scale, the $A_{\mathrm{NP}}$ ranged from 294 to $964 \mathrm{mmol} \mathrm{N} \mathrm{m}^{-2} \mathrm{yr}^{-1}$; if calculated from $\mathrm{GP}$, the values are approximately doubled (Table 1). Comparing daily $A_{\mathrm{NP}}$ values (Fig. 2A) with the calculated light-related inorganic nitrogen (IN) uptake per day (0 to $1560 \mu \mathrm{mol} \mathrm{m} \mathrm{m}^{-2} \mathrm{~d}^{-1}$ ) (Fig. 2B) shows that the $\mathrm{N}$ demand far exceeds the actual measured daily uptake of IN. Lightrelated IN uptake was calculated as the difference between a 24 h dark flux (= $24 \times$ hourly dark flux rates) and daily IN flux [= (number of daylight hours $\times$ the hourly rate in light) + (number of dark hours $\times$ hourly rate in the dark)]. Calculated $\mathrm{N}$ assimilation showed a significant positive correlation with light-related IN uptake for the sandy site $(p<0.01)$, but not for the silty site (Fig. 3).

The magnitude of $\mathrm{N}$ retained in the microalgal biomass on an annual basis can be estimated from the annual mean concentrations of sediment chl $a$, assuming a $\mathrm{C} / \mathrm{chl}$ a ratio of 30 and a $\mathrm{C} / \mathrm{N}$ molar

Stn $C$ being occasionally significantly lower than at Stn D [time $\times$ station (site)] ( $\mathrm{p}=0.0001)$ (Fig. 1B).

Annual NP was 7 to $7.5 \mathrm{~mol} \mathrm{C} \mathrm{m} \mathrm{Cr}^{-1}$ (or 84.5 to $89.8 \mathrm{~g} \mathrm{C} \mathrm{m}^{-2} \mathrm{yr}^{-1}$ ) for the 2 sandy stations (Stns A ratio of 9 (see 'Material and methods' and 'Discussion; Methods'). The mean annual estimate of $\mathrm{N}$ retention in microalgal biomass was ca $16 \mathrm{mmol} \mathrm{N} \mathrm{m} \mathrm{m}^{-2}$ for Vallda and 8 to $10 \mathrm{mmol} \mathrm{N} \mathrm{m}^{-2}$ for Rörtången

Table 1. Annual gross (GP), net primary productivity (NP), calculated annual N assimilation of microphytobenthos based on GP $\left(A_{\mathrm{GP}}\right)$ and NP $\left(A_{\mathrm{NP}}\right)$, mean annual retention of $\mathrm{N}$ in microalgal biomass $\left(N_{\text {bio }}\right)$, total denitrification $\left(D_{\text {tot }}\right)$ and the ratios $A_{\mathrm{GP}} / D_{\text {tot }}$ and $A_{\mathrm{NP}} / D_{\text {tot }}$. Algal nitrogen assimilation and retention is based on a C/N ratio of 9 . GP and $\mathrm{NP}$ are expressed as $\mathrm{mol} \mathrm{C} \mathrm{m}^{-2} \mathrm{yr}^{-1}$; all other values are expressed as mmol $\mathrm{N} \mathrm{m}^{-2} \mathrm{yr}^{-1}$

\begin{tabular}{|lccccrrrr|}
\hline Stn & $\mathrm{GP}$ & $\mathrm{NP}$ & $A_{\mathrm{GP}}$ & $A_{\mathrm{NP}}$ & $N_{\text {bio }}$ & $D_{\text {tot }}$ & $A_{\mathrm{GP}} / D_{\text {tot }}$ & $A_{\mathrm{NP}} / D_{\text {tot }}$ \\
\hline Vallda A (sand) & 11.8 & 7.0 & 1306 & 783 & 15.8 & 12.1 & 107.9 \\
Vallda B (sand) & 13.3 & 7.5 & 1472 & 832 & 16.2 & 11.1 & 132.6 & 74.7 \\
Rörtången C (silt) & 6.6 & 2.6 & 739 & 294 & 8.1 & 105.2 & 7.0 & 2.8 \\
Rörtången D (silt) & 16.4 & 8.7 & 1822 & 964 & 10.5 & 144.4 & 12.6 & 6.7 \\
\hline
\end{tabular}


A
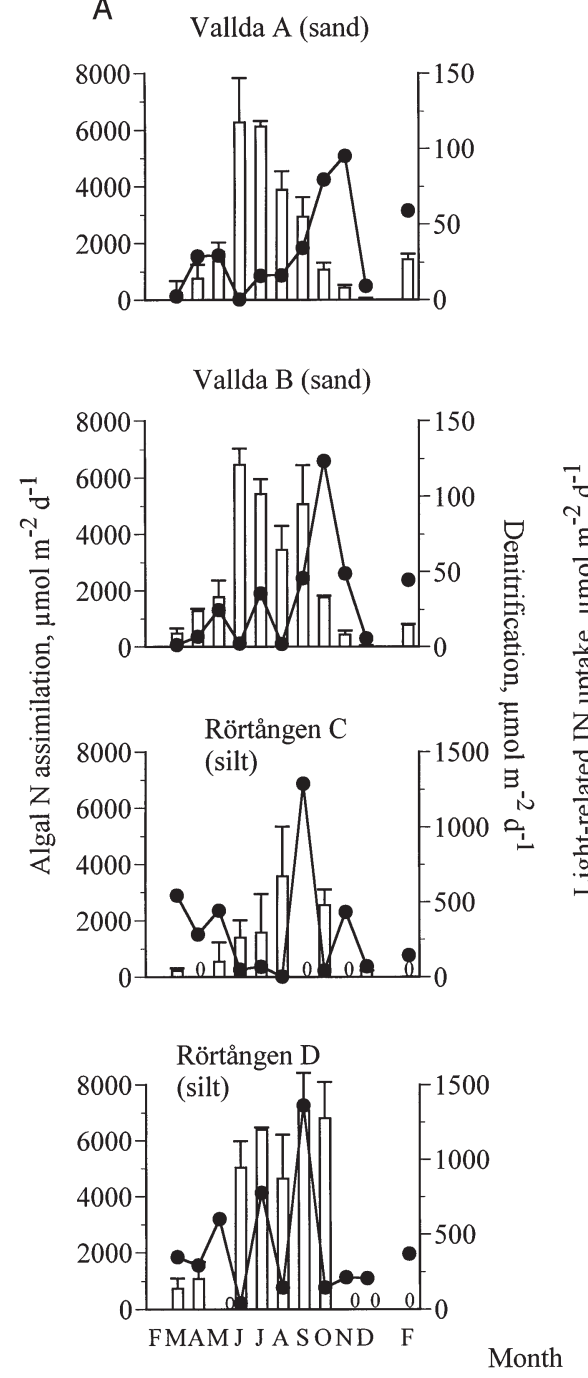

B
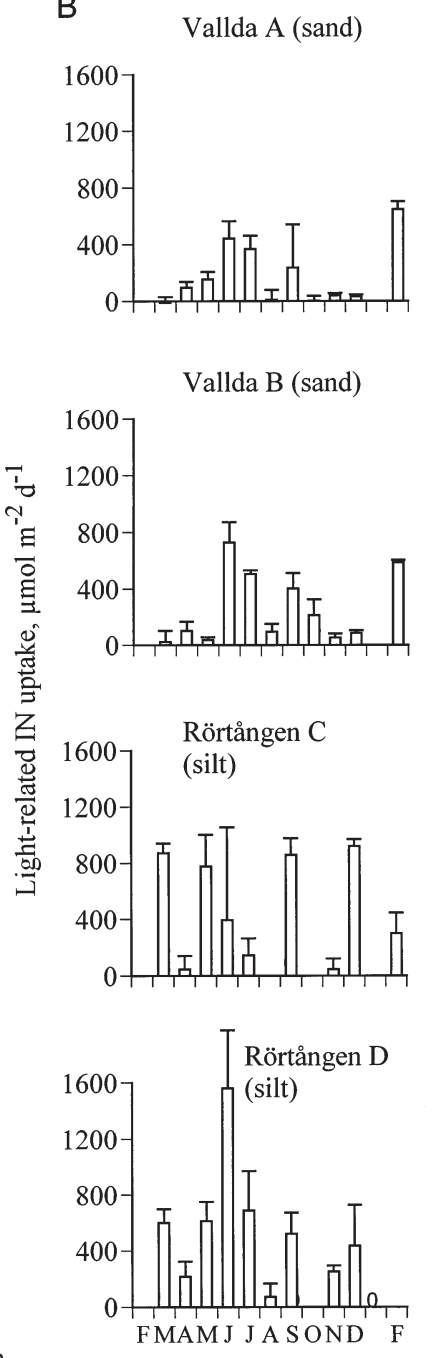

Fig. 2. (A) Calculated microphytobenthic $\mathrm{N}$ assimilation (bars) based on net primary productivity $(\mathrm{C} / \mathrm{N}=9)$ and measured total denitrification (line) and (B) light-related daily inorganic nitrogen (IN) flux (24 h dark flux - daily light/dark flux) for the 4 stations. Means of 3 replicates + SE are shown. No measure of variation is shown for daily denitrification, as light and dark measurements were not paired. Note that axis scales for denitrification differ between Vallda and Rörtången

(Table 1). Comparing these values with the annual $A_{\mathrm{NP}}$ gives a turnover time of algal $\mathrm{N}$ within the range of 4 to $10 \mathrm{~d}$, with the highest turnover found for the silty Stn D. If compared with $A_{\mathrm{GP}}$, the calculated turnover rates are 2 to $4 \mathrm{~d}$.

\section{Denitrification}

Total denitrification $\left(D_{\text {tot }}\right)$ was generally an order of magnitude higher at the silty site $(2.7$ to $1361 \mu \mathrm{mol}$ $\left.\mathrm{m}^{-2} \mathrm{~d}^{-1}\right)$ compared with the sandy site $(0.4$ to

$124 \mu \mathrm{mol} \mathrm{m} \mathrm{m}^{-2} \mathrm{~d}^{-1}$ ) (Fig. 2A, lines). At the sandy site, the highest denitrification rates were found in autumn, while at the silty stations the pattern was more erratic, although there was a tendency for higher rates in spring, but peak rates were also measured in September and July. Daily denitrification was significantly correlated with the $\mathrm{NO}_{3}$ concentration in the overlying water for the sandy site $(r=0.643, p<0.001)$, but not for the silty site.

\section{Balance between algal assimilation and retention and denitrification}

Algal retention and denitrification can be compared in 2 ways, either by comparing rates on different time scales or by comparing the amount of $\mathrm{N}$ lost through denitrification with the actual retention in the algal standing stock over a period of time, e.g. over $1 \mathrm{yr}$. The latter approach is probably a severe underestimation, as $\mathrm{N}$ assimilated by algae during the year is transferred to heterotrophic biomass and buried, as well as recirculated within the system.

At the sandy site, $A_{\mathrm{NP}}$ exceeded $D_{\text {tot }}$ throughout the year by approximately 2 orders of magnitude, with the exception of the low-productivity period November-December (Fig. 2, Table 2). At the silty site, the $A_{\mathrm{NP}} / D_{\text {tot }}$ ratios were significantly lower than in the sandy sediment, and denitrification occasionally exceeded assimilation (Table 2). At Vallda, there was a clear seasonal pattern, with highest assimilation/dentrification ratios being found in summer. At Rörtången, the temporal pattern was more erratic, although the highest assimilation/ dentrification ratios were found during the warm season. On an annual scale, calculated $A_{\mathrm{NP}}$ exceeded denitrification at both sites (Table 1). For the sandy stations, the annual $A_{\mathrm{NP}} / D_{\text {tot }}$ ratio was 65 to 74 $\left(A_{\mathrm{GP}} / D_{\text {tot }}\right.$ approximately double), while the corresponding values for the 2 silty stations were 2.8 and 6.7 $\left(A_{\mathrm{GP}} / D_{\text {tot }}=7\right.$ to 12.6$)$, suggesting a more balanced relationship between assimilation and denitrification (Table 1).

When comparing the amount of $\mathrm{N}$ retained in the mean annual algal biomass $\left(N_{\text {bio }}\right)$ with $D_{\text {tot, }}$ it appears that for the sandy site, these 2 sinks are more or less equal, while for the silty site the amount of $\mathrm{N}$ removed during the year exceeds the 'standing' pool retained in the algal biomass (Table 1 ). 


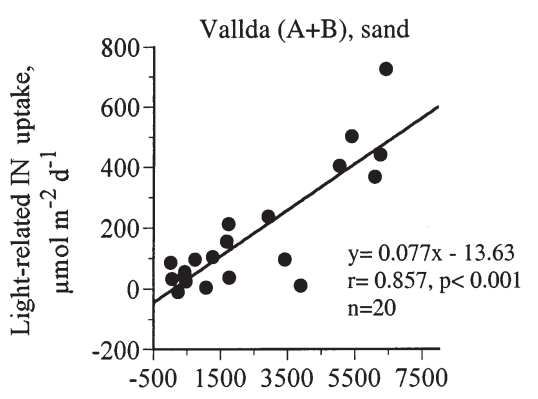

Calculated $\mathrm{N}$-assimilation, $\mu \mathrm{mol} \mathrm{N} \mathrm{m} \mathrm{m}^{-2} \mathrm{~d}^{-1}$

Fig 3. Correlation between calculated $\mathrm{N}$ assimilation by microphytobenthos and light-related daily IN uptake (24 h dark flux - daily light/dark flux) for Vallda (sand) and Rörtången (silt)

\section{DISCUSSION}

\section{Methods}

The fact that the incubations were made in the laboratory, and not in situ, could perhaps be considered a weakness in this study, although this is a widely adopted approach for studies of sediment fluxes. Nielsen \& Glud (1996), who compared denitrification measurements in benthic chambers in situ and in cores in the laboratory, found no significant differences in results from the 2 methods. The advantages of controlled laboratory incubations, in approximate in situ conditions, are that the risk of failure is minimized and the effect of stochastic events removed. Using a monthly mean light level also minimized the effect of stochastic weather changes, particularly as only 1 incubation series was run per month. A strength of our study is that our conclusions are based on more than 600 core incubations covering a full seasonal cycle.

In order to calculate algal $\mathrm{N}$ incorporation, some general assumptions had to be adopted. Nitrogen assimilation was estimated indirectly from daily primary production assuming a close link between $\mathrm{C}$ and $\mathrm{N}$ assimilation. Although this approach can be criticized, as the $\mathrm{C} / \mathrm{N}$ ratio is known to vary greatly (Hillebrand \& Sommer 1997), the Redfield $\mathrm{C} / \mathrm{N}$ ratio of 6.6 has been frequently used to estimate $\mathrm{N}$ demand of plankton systems. Instead of the Redfield ratio, we used a ratio of 9 . To our knowledge there are no published $\mathrm{C} / \mathrm{N}$ ratios of natural marine microalgal communities from sediments, but studies on cultured benthic diatoms and periphyton suggest $\mathrm{C} / \mathrm{N}$ ratios within the
Table 2. Ratios between mean monthly rates of algal $\mathrm{N}$ assimilation (calculated from net primary productivity assuming a $\mathrm{C} / \mathrm{N}$ ratio of 9 ) and total denitrification $\left(A_{\mathrm{NP}} / D_{\text {tot }}\right)$ for the 4 stations. A $\gg \mathrm{D}$ indicates ratios $>1000$ and $\mathrm{A} \gg \mathrm{D}$ indicates no NP. Ratios are based on daily rates $\left(\mu \mathrm{mol} \mathrm{N} \mathrm{m} \mathrm{N}^{-2} \mathrm{~d}^{-1}\right)$

\begin{tabular}{|lcccc|}
\hline Month & $\begin{array}{c}\text { Vallda A } \\
\text { (sand) } \\
A_{\mathrm{NP}} / D_{\text {tot }}\end{array}$ & $\begin{array}{c}\text { Vallda B } \\
\text { (sand) } \\
A_{\mathrm{NP}} / D_{\text {tot }}\end{array}$ & $\begin{array}{c}\text { Rörtången C } \\
\text { (silt) } \\
A_{\mathrm{NP}} / D_{\text {tot }}\end{array}$ & $\begin{array}{c}\text { Rörtången D } \\
\text { (silt) } \\
A_{\mathrm{NP}} / D_{\text {tot }}\end{array}$ \\
\hline Mar & 98 & 364 & 0.4 & 2.1 \\
Apr & 26 & 184 & $\mathrm{~A}<<\mathrm{D}$ & 3.7 \\
May & 58 & 71 & 1.2 & $\mathrm{~A} \ll \mathrm{D}$ \\
Jun & $\mathrm{A} \gg \mathrm{D}$ & $\mathrm{A} \gg \mathrm{D}$ & 29 & 132 \\
Jul & 378 & 153 & 23 & 8.3 \\
Aug & 234 & $\mathrm{~A} \gg \mathrm{D}$ & $\mathrm{A} \gg \mathrm{D}$ & 32 \\
Sep & 85 & 110 & $\mathrm{~A} \gg \mathrm{D}$ & 5.2 \\
Oct & 13.5 & 14 & 58 & 47 \\
Nov & 4.5 & 9 & $\mathrm{~A} \gg \mathrm{D}$ & $\mathrm{A} \gg \mathrm{D}$ \\
Dec & 5.2 & 6 & 0.2 & $\mathrm{~A} \gg \mathrm{D}$ \\
Feb & 24.6 & 17.5 & 0.9 & $\mathrm{~A} \gg \mathrm{D}$ \\
& & & & \\
\hline
\end{tabular}


spring at the sandy site. This might be explained by a low grazing pressure, particularly by mud snails Hydrobia spp., the numbers of which increase later in the year. Hydrobia are considered to be important grazers of microphytobenthos (Asmus \& Asmus 1985, Duarte \& Cebrián 1996). Our own preliminary grazing measurements applying in situ ${ }^{14} \mathrm{C}$-labelling (see Montagna 1993) also suggest a considerable grazing pressure by H. ulvae (Sundbäck \& Grudemo unpubl.).

The fact that the microphytobenthic biomass was present throughout the year implies that there was a constant pool of $\mathrm{N}$ bound to this biomass, although the activity of the biomass was lower during the cold season. An effect of light on IN flux was seen all year round, with a few exceptions for the silty site (Fig. 2B). This agrees with the results of others (Rizzo 1990, Sundbäck et al. 1991, Asmus et al. 1998, Thornton et al. 1999 and references therein). That this effect was a result of algal activity was corroborated by a highly significant correlation between daily NP and lightrelated IN uptake in the sandy sediment (Fig. 3). However, this relationship was less clear at the silty site, which may be related to a less $\mathrm{N}$-limited situation.

Even if algal $\mathrm{N}$ assimilation based on NP is an underestimation, it shows that assimilation rates far exceed the measured light-related net uptake of IN at both sites (Fig. 2). This suggests that sediment pore water must be a substantial N source for the algae (cf. Nilsson \& Sundbäck 1991, Nilsson et al. 1991, Flothmann \& Werner 1992). It is interesting to note that substantial microphytobenthic NP occurred even though nutrient concentrations in the overlying water were close to the detection limit. This implies that a rapid recirculation of nutrients is important in these systems. This assumption agrees with the findings by Lomstein et al. (1998), who studied the remineralisation processes in a similar sandy sediment colonized by benthic microphytes in the Kattegat. They found that the mineralisation rate of $\mathrm{NH}_{4}$ was an order of magnitude higher than the actual sediment efflux of $\mathrm{NH}_{4}$ and proposed that this discrepancy is caused by uptake by microorganisms at the sediment surface. They also concluded that sediment mineralization was through a closed cycle of alternate organic N degradation and resynthesis driven by carbon oxidation and that this pattern was typical of low-N areas. This fits particularly well with the situation at our sandy site, where 'old production' (in the sense of Dudgale \& Goering 1967) appeared to dominate during most of the year.

\section{Balance between $\mathrm{N}$-assimilation and denitrification}

While biomass and primary productivity differed only in the temporal pattern between the sandy and silty site, denitrification varied by an order of magnitude, being higher at the silty site. This difference was consequently manifested in the different assimilation/denitrification ratios (Tables $1 \& 2$ ). At the sandy site, algal assimilation always far exceeded the rates of denitrification. The observed low denitrification values (mostly $<100 \mu \mathrm{mol} \mathrm{m} \mathrm{m}^{-2} \mathrm{~d}^{-1}$ ), however, agree well with rates found for similar littoral sediments in the Gulf of Riga, SE Baltic Sea (Sundbäck et al. 1998), measured by the same method (see also Table 3, but note that hourly rates are given). The maximum denitrification rates for Danish sediments with low concentrations of

Table 3. Average hourly values for microphytobenthic $\mathrm{N}$ assimilation $\left(A_{\mathrm{NP}}\right)$, calculated from net primary productivity (photosynthetic quotient $=1.2, \mathrm{C} / \mathrm{N}=9)$, and rates for total denitrification in the dark $\left(D_{\text {tot }}\right)$ and their ratio for sediment from 6 brackishwater sites in the Baltic Sea area. Ratios have been calculated only for sampling occasions when a net primary productivity was found. Denitrification has been measured by the isotope-pairing technique (Nielsen 1992). Net primary productivity (NP) was measured as net $\mathrm{O}_{2}$ flux in light, except for the Gulf of Riga, where an in situ ${ }^{14} \mathrm{C}$-percolation technique was used (Jönsson 1991). Values for $A_{\mathrm{NP}}$ and $D_{\text {tot }}$ are expressed as $\mu \mathrm{mol} \mathrm{N} \mathrm{m}^{-2} \mathrm{~h}^{-1}$

\begin{tabular}{|c|c|c|c|c|c|c|}
\hline Site & Sediment & Depth (m) & $A_{\mathrm{NP}}$ & $D_{\text {tot }}$ & $A_{\mathrm{NP}} / D_{\text {tot }}$ & Source \\
\hline Kertinge Fjord, Belt Sea ${ }^{a}$ & Sand & 0.5 & 108 & 34 & 3.2 & Rysgaard et al. (1995) (Figs. $2 \& 4$ ) \\
\hline Skive Fjord, Limfjorden ${ }^{\mathrm{b}}$ & Silt & 5.5 & 256 & 25 & 10.2 & Dalsgaard et al. (1999) \\
\hline \multirow[t]{2}{*}{ Saaremaa, NW Gulf of Riga } & $\mathrm{a}^{\mathrm{c}}$ Sand & 0.2 & 134 & 6.6 & 20.3 & Sundbäck et al. (1998) \\
\hline & Sand & 0.5 & 74 & 5.6 & 13.2 & Sundbäck et al. (1998) \\
\hline \multirow[t]{3}{*}{ Saukrasti, E Gulf of Riga ${ }^{c}$} & Sand & 1 & 74 & 3.3 & 22.4 & Sundbäck et al. (1998) \\
\hline & Sand & 3 & 50 & 5.9 & 8.5 & Sundbäck et al. (1998) \\
\hline & Sand & 5 & 4.3 & 2.8 & 1.5 & Sundbäck et al. (1998) \\
\hline Vallda, NE Kattegat ${ }^{\mathrm{d}}$ & Sand & 0.5 & 124 & 1.6 & 79 & Sundbäck et al. (2000) \\
\hline Rörtången, NE Kattegat $^{\mathrm{d}}$ & Silt & 0.5 & 129 & 20.5 & 6.3 & Sundbäck et al. (2000) \\
\hline \multicolumn{7}{|c|}{$\begin{array}{l}{ }^{\text {a } V a l u e s ~ i n c l u d e d ~ f o r ~ t h e ~ p e r i o d s ~ F e b r u a r y ~ t o ~ A p r i l ~ a n d ~ O c t o b e r-N o v e m b e r, ~ i n c u b a t i o n ~ i n ~ t h e ~ l a b o r a t o r y ~ a t ~} 70 \text { to } 120 \mu \mathrm{mol} \text { pho- } \\
\text { tons } \mathrm{m}^{-2} \mathrm{~s}^{-1}\end{array}$} \\
\hline
\end{tabular}


$\mathrm{NO}_{3}$ have been found to be ca $500 \mu \mathrm{mol} \mathrm{m}{ }^{-2} \mathrm{~d}^{-1}$ (L.-P. Nielsen pers. comm. cited in Lomstein et al. 1998). A significant positive correlation with the $\mathrm{NO}_{3}$ concentration in the overlying water and a significant negative correlation with NP suggest that microalgae compete with bacteria for most of the year (cf. Rysgaard et al. 1995). Apparently, photoautotrophs outcompete denitrification bacteria in this type of sandy sediment, with deep $\mathrm{O}_{2}$ penetration and low nitrogen availability. This conclusion is also supported by the fact that light generally had a significant negative effect on hourly denitrification rates (Sundbäck et al. 2000). It appears then that, when compared with microalgal $\mathrm{N}$ turnover, denitrification plays a minor role in $\mathrm{N}$ removal in sandy microtidal sediments, at least in the shallowest waters.

For the silty sediment, the $A_{\mathrm{NP}} / D_{\text {tot }}$ ratios were approximately an order of magnitude lower than for the sandy sediment, and occasionally denitrification rates even exceeded calculated $\mathrm{N}$-assimilation rates (Table 2). On an annual scale, $A_{\mathrm{NP}}$ still exceeded $D_{\text {tot }}$ (Table 1). Higher denitrification rates in finer sediments have also been found by others (Jensen et al. 1996, Nowicki et al. 1997), and can be explained by a better availability of carbon and nitrogen for denitrifiers, as well as by a shallower $\mathrm{O}_{2}$ penetration than in sandy sediment. The lack of an overall correlation between NP and light-related IN uptake (Fig. 3) suggests that $\mathrm{N}$ limitation was less important at this silty site.

The mean amount of $\mathrm{N}$ retained in the microalgal biomass (calculated from chl a) was ca 8 to $16 \mathrm{mmol} \mathrm{N}$ $\mathrm{m}^{-2} \mathrm{yr}^{-1}$ (Table 1). Still, for the sandy site, algal retention was ca 1.5 times greater than denitrification on an annual scale. For the silty site, $D_{\text {tot }}$ on the other hand was ca 13 times higher than the amount of $\mathrm{N}$ bound to biomass, further demonstrating the greater importance of denitrification at the silty site. However, as pointed out earlier, mean annual standing stock is an underestimation of $\mathrm{N}$ retention, as no attention is paid to the fact that $\mathrm{N}$ is both moved further in the food web and buried in the sediment. According to the compilation by Duarte \& Cebrián (1996), ca $43 \%$ of the microphytobenthic NP goes to grazers and $25 \%$ is buried. Although denitrification was generally 10 times more important in the silty sediment than the sandy sediment, microphytobenthic assimilation still appeared to be the dominating process decreasing bioavailable $\mathrm{N}$ on an annual scale in both systems (Table 1).

Table 3 compiles measured hourly rates of $D_{\text {tot }}$ in darkness (measured by the isotope-pairing technique), calculated $A_{\mathrm{NP}}$ and their ratio for some shallow-water microtidal sediments from the south and western Baltic Sea area. Although light has been shown to affect denitrification (Risgaard-Petersen et al. 1994, Rysgaard et al. 1995, Currin et al. 1996), $D_{\text {tot }}$ in darkness was chosen here, as light rates were not measured in all stud- ies. With the exception of a low value at a deeper site in the Gulf of Riga, calculated $A_{\mathrm{NP}}$ values only differ by a factor of ca 2 . $D_{\text {tot }}$ values were roughly within the range of 2 to $30 \mu \mathrm{mol} \mathrm{N} \mathrm{m} \mathrm{N}^{-2} \mathrm{~h}^{-1}$ and 1 to 2 orders of magnitude lower than the calculated $A_{\mathrm{NP}}$. Even if the material is limited, and incubation methods vary, the comparison supports the hypothesis that microalgal assimilation exceeds denitrification in northern shallow-water $(<5 \mathrm{~m})$ microtidal sediments.

The general pattern that emerged from this study was that shallow-water microtidal sediments are characterised by substantial microalgal $\mathrm{N}$ assimilation and low denitrification rates. Denitrification is known to be controlled by several microbe-level processes, such as substrate availability (nitrate), oxygen inhibition and organic matter supply, while on a larger, ecosystem scale it is controlled by physical and chemical factors, such as seasonality and hydrodynamics (Kana et al. 1998 and references therein). For our sites, 3 reasons for a low denitrification rate may apply: (1) low external substrate availability, except in winter, (2) competition for both external and internally circulated substrate by microalgae inhabiting the surface of the sediment, and (3) a general negative effect of microalgal activity on denitrifiers (cf. Rysgaard et al. 1995). However, increased denitrification with temporary pulses of available substrate suggests that there is a potential for a rapid response of the denitrification capacity in the sediments studied. Others have shown that sediments can react rapidly to an increased $\mathrm{NO}_{3}$ load (Joye \& Paerl 1993, Kana et al. 1998).

Not withstanding the limitations of this study (limited coverage of water depths and sediment types, indirect measurements of algal $\mathrm{N}$ assimilation), it provides some novel data by comparing 2 simultaneously measured $\mathrm{N}$ removing processes, both mediated by microscopic organisms inhabiting surface sediments. The results suggest that the microphytobenthos, in microtidal sediments, is a substantial $N$ sink during the majority of the year and that, particularly in sandy sediments, $\mathrm{N}$ retention by microphytobenthos is more important than the final $\mathrm{N}$ removal through denitrification. However, in order to verify the balance between autotrophic and heterotrophic $\mathrm{N}$ turnover, we need (1) better knowledge of the variation of $\mathrm{C} / \mathrm{N}$ ratios of natural communities of sediment microphytobenthos, (2) to verify the microphytobenthic assimilation rates by direct measurements by, e.g. ${ }^{15} \mathrm{~N}$ uptake, (3) to study the processes on a larger spatial scale (different depths, sediment types) and finally, (4) to relate the importance of microphytobenthos to the role of other primary-producing components in sediment areas, such as macrophytes and floating macroalgae. To evaluate the regional importance, knowledge of water retention and $\mathrm{N}$ load also needs to be included by modeling. 
Acknowledgements. This research has been undertaken in the framework of the NICE project. We acknowledge the support from the European Commission's Marine Science and Technology Programme (MAST III) under contract MAS3CT96-0048. National funding for the project was received from the Swedish Environmental Protection Agency and NUTEK. Further support was received from the Swedish Natural Science Research Council (TRAACS analytical system), the Fund of Captain Stenholm and The Royal Society of Arts and Sciences in Göteborg. The authors thank Eva Göransson for co-operation and Rosa Viejo, Frank Linares, Silvia Gogg, Monica Appelgren and Mireille Consalvey for assistance in the field. We appreciate the constructive comments by 2 anonymous referees.

\section{LITERATURE CITED}

Asmus H, Asmus R (1985) The importance of grazing food chain for energy flow and production in three intertidal sand bottom communities of the northern Wadden Sea. Helgol Meeresunters 39:273-301

Asmus RM, Jensen MH, Jensen KM, Kristensen E, Asmus H, Wille A (1998) The role of water movement and spatial scaling for measurement of dissolved inorganic nitrogen fluxes in intertidal sediments. Estuar Coast Shelf Sci 46: $212-232$

Brzezinski MA (1985) The Si:C:N ratio of marine diatoms: interspecific variability and the effect of some environmental variables. J Phycol 21:347-357

Currin CA, Joye SB, Paerl HW (1996) Diel rates of $\mathrm{N}_{2}$-fixation and denitrification in a transplanted Spartina alterniflora marsh: implications for $\mathrm{N}$-flux-dynamics. Estuar Coast Shelf Sci 42:597-616

Daehnick AE, Sullivan MJ, Moncreiff CA (1992) Primary production of the sand microflora in seagrass beds of Mississippi Sound. Bot Mar 35:131-139

Dalsgaard T (ed) (1999) Final Scientific report for NICENitrogen cycling in estuaries: a project under the EU research programme: marine Science and Technology (MAST III). National Environmental Research Institute, Silkeborg

Dalsgaard T, Christensen PB, Rysgaard S, Risgaard-Petersen N (1999) Nitrogen removal in Danish coastal waters: importance and regulation (in Danish). In: Lomstein BA (ed) Marine environments into the millenium. Olsen \& Olsen, Fredensborg, p 102-118

Dalsgaard T (ed), Nielsen LP, Brotas V, Viaroli P, Underwood G, Nedwell DB, Sundbäck K, Miles A, Bartoli M, Dong L, Thornton DCO, Ottosen LDM, Castadelli G, RisgaardPetersen N (2000) Protocol handbook for NICE - Nitrogen cycling in estuaries: a project under the EU research programme: marine Science and Technology (MAST III). National Environmental Research Institute, Silkeborg

de Jonge VN (1980) Fluctuations in the organic carbon to chlorophyll a ratios for estuarine benthic diatom populations. Mar Ecol Prog Ser 2:345-353

Duarte CM, Cebrián J (1996) The fate of marine autotrophic production. Limnol Oceanogr 41:1758-1766

Dudgale RC, Goering JJ (1967) Uptake of new and regenerated forms of nitrogen in primary productivity. Limnol Oceanogr 12:196-206

Flothmann S, Werner I (1992) Experimental eutrophication on an intertidal sandflat: effects on microphytobenthos, meioand macrofauna. In: Colombo G, Ferrari I, Ceccherelli VU, Rossi R (eds) Marine eutrophication and population dynamics. Olsen \& Olsen, Fredensborg, p 93-100
Grasshoff K, Erhardt M, Kremling K (1983) Methods of seawater analyses, 2nd edn. Verlag Chemie, Weinheim

Herndl GJ, Peduzzi P, Fanuko N (1989) Benthic community metabolism and microbial dynamics in the Gulf of Trieste (Northern Adriatic Sea). Mar Ecol Prog Ser 53:169-178

Hillebrand H, Sommer U (1997) Response of epilithic microphytobenthos of the Western Baltic Sea to in situ experiments with nutrient enrichment. Mar Ecol Prog Ser 160: $35-46$

Jensen KM, Jensen MH, Kristensen E (1996) Nitrification and denitrification in Wadden Sea sediments (Koenigshafen, Island of Sylt, Germany) as measured by nitrogen isotope pairing and dilution. Aquat Microb Ecol 11: 181-191

Joye SB, Paerl HW (1993) Contemporaneous nitrogen fixation and denitrification in intertidal microbial mats: rapid response to runoff events. Mar Ecol Prog Ser 94:267-274

Kahlert M (1998) C:N:P ratios of freshwater benthic algae. Arch Hydrobiol Spec Iss Adv Limnol 51:105-114

Kana TM, Sullivan MB, Cornwell JC, Groszkowski KM (1998) Denitrification in estuarine sediments determined by membrane inlet mass spectrometry. Limnol Oceanogr 43: 334-339

Kühl M, Glud RN, Ploug H, Ramsing NB (1996) Microenvironmental control of photosynthesis and photosynthesiscoupled respiration in an epilithic cyanobacterial film. J Phycol 32:799-812

Lomstein BA, Jensen AGU, Hansen JW, Andreasen JB, Hansen LS, Berntsen J, Kunzendorf H (1998) Budgets of sediment nitrogen and carbon cycling in the shallow water of Knebel Vig, Denmark. Aquat Microb Ecol 14:69-80

Lorenzen CJ (1967) Determination of chlorophyll and pheopigments: spectrophotometric equations. Limnol Oceanogr 12:343-346

Montagna PA (1993) Radioisotope technique to quantify in situ microherbivory by meiofauna in sediments. In: Kemp PF, Sherr BF, Sherr EB, Cole JJ (eds) Handbook of methods in aquatic microbial ecology. Lewis Publishers, Boca Raton, p 745-753

Nielsen LP (1992) Denitrification in sediment determined from nitrogen isotope pairing. FEMS Microbiol Ecol 86: 357-362

Nielsen LP, Glud RN (1996) Denitrification in a coastal sediment measured in situ by the nitrogen isotope pairing technique applied to a benthic flux chamber. Mar Ecol Prog Ser 137:181-186

Nilsson C, Sundbäck K (1991) Growth and nutrient uptake studied in sand-agar microphytobenthic communities. J Exp Mar Biol Ecol 153:207-226

Nilsson P, Jönsson B, Lindström Swanberg I, Sundbäck K (1991) Response of a marine shallow-water sediment system to an increased load of inorganic nutrients. Mar Ecol Prog Ser 71:275-290

Nixon SW (1995) Coastal marine eutrophication: a definition, social causes, and future concerns. Ophelia 41:199-219

Nowicki BL, Requintina E, Van Keuren D, Kelly JR (1997) Nitrogen losses through sediment denitrification in Boston Harbor and Massachusetts Bay. Estuaries 20:626-639

Pedersen MF, Borum J (1993) An annual nitrogen budget for a seagrass Zostera marina population. Mar Ecol Prog Ser 101:169-177

Pihl L, Magnusson G, Isaksson I, Wallentinus I (1996) Dstribution and growth dynamics of ephemeral macroalgae in shallow bays on the Swedish west coast. J Sea Res 35: 169-180

Revsbech NP (1989) An oxygen microelectrode with a guard cathode. Limnol Oceanogr 34:474-478 
Risgaard-Petersen N, Ottosen LDM (2000) Nitrogen cycling in two temperate Zostera marina beds: seasonal variation. Mar Ecol Prog Ser 198:93-107

Risgaard-Petersen N, Rysgaard S, Nielsen LP, Revsbech NP (1994) Diurnal variation of denitrification and nitrification in sediments colonized by benthic microphytes. Limnol Oceanogr 39:573-579

Rizzo WM (1990) Nutrient exchanges between the water column and a subtidal benthic microalgal community. Estuaries 13:219-226

Rysgaard S, Christensen PB, Nielsen LP (1995) Seasonal variation in nitrification and denitrification in estuarine sediment colonized by benthic microalgae and bioturbating infauna. Mar Ecol Prog Ser 126:111-121

Seitzinger SP (1988) Denitrification in freshwater and coastal marine ecosystems: ecological and geochemical significance. Limnol Oceanogr 33:702-724

Strickland JDH, Parsons TR (1972) A practical handbook of seawater analysis, 2nd edn. Bull Fish Res Board Can 167

Sundbäck K, Jönsson B (1988) Microphytobenthic productivity and biomass in sublittoral sediments of a stratified bay, southeastern Kattegat. J Exp Mar Biol Ecol 122:63-81

Sundbäck K, Enoksson V, Granéli W, Pettersson K (1991) Influence of sublittoral microphytobenthos on the oxygen and nutrient flux between sediment and water: a laboratory continuous-flow study. Mar Ecol Prog Ser 74:263-279

Sundbäck K, Nilsson P, Nilsson C, Jönsson B (1996) Balance

Editorial responsibility: Gary King, Walpole, Maine, USA between autotrophic and heterotrophic components and processes in microbenthic communities of sandy sediments: a field study. Estuar Coast Shelf Sci 43:689-706

Sundbäck K, Nilsson C, Stockenberg A (1998) Microphytobenthic primary productivity and bacterial nitrogen turnover in the littoral sediments of the Gulf of Riga. Final Report to the Nordic Council of Ministers. Botanical Institute, Göteborg

Sundbäck K, Miles A, Göransson E (2000) Nitrogen fluxes, denitrification and the role of microphytobenthos in microtidal shallow-water sediments: an annual study. Mar Ecol Prog Ser 200:59-76

Thornton DCO, Underwood GJC, Nedwell DB (1999) Effect of illumination and emersion period on the exchange of ammonium across the estuarine sediment-water interface. Mar Ecol Prog Ser 184:11-20

Underwood AJ (1997) Experiments in ecology. Cambridge University Press, Cambridge

Underwood GJC, Kromkamp J (1999) Primary production by phytoplankton and microphytobenthos in estuaries. Adv Ecol Res 29:93-153

Viaroli P, Bartoli M, Bondavalli C, Christian RR (1996) Macrophyte communities and their impact on benthic fluxes of oxygen, sulphide and nutrients in shallow eutrophic environments. Hydrobiologia 329:105-119

Wetzel RG, Likens GE (1991) Limnological analyses, 2nd edn. Springer-Verlag, Berlin

Submitted: January 25, 2000; Accepted: July 19, 2000 Proofs received from author(s): October 9, 2000 